\title{
The Application of Cooperative Learning Model Type of STAD to Vocabulary Mastery of Student Grade 5 Elementary School at 9 Kesiman in Making Simple English Sentences
}

\author{
dayuariputri95@yahoo.com ${ }^{1}$,darmalaksana2020@gmail.com², md_madia@unud.ac.id ${ }^{3}$ \\ Universitas Udayana, Denpasar 80114, Indonesia
}

\begin{abstract}
This study aims to find out: (1) Students' vocabulary mastery in making simple English sentences before applying STAD type cooperative learning methods; 2) Students 'vocabulary mastery in making simple English sentences after applying STAD type cooperative learning methods, (3) Effectiveness of applying STAD type cooperative learning models on increasing students' English vocabulary mastery in making simple sentences. This is a type of experimental research with qualitative and quantitative approaches. In this study using one group pretest and posttest research. The subjects of this study were 30 students in grade 5 SDN 9 Kesiman while the object was the mastery of students' vocabulary in making simple sentences. Data were collected through observation, questionnaires, and written tests. Qualitative and quantitative methods are applied in analyzing data. The results showed that: (1) There were 10 students whose $37.5 \%$ of the subjects were in the standard completeness score $>60$. Meanwhile, the remaining 20 students namely $62.5 \%$ had not yet reached the standard completeness score. The average student score is 50.5 and it is quite low. Errors found in answering objective questions and making simple sentences lie in sentence structure, subject-verb relations, word choices, spelling, and use of punctuation. This error is categorized as a lack of student mastery of English vocabulary so that when students are asked to make and translate simple sentences in English there are still many that are lacking; (2) STAD is applied in 2 test sessions. The number of students who achieved the standard completeness score increased to 27 students or $87.5 \%$ while only 3 students or $12.5 \%$ did not meet the standard. The average value of students reaching 77.8 is categorized as good. Based on the Wilcoxon test output the significance value is 0.00 because the value is below 0.05 which is the significance value rate of the Wilcoxon test so it can be concluded that the cooperative learning type of STAD can significantly affect student learning outcomes. (3) The effectiveness of applying STAD type cooperative learning methods to increase students' vocabulary mastery in constructing simple sentences are: (1) an encouraging classroom atmosphere; (2) non-boring learning methods; (3) effective, relaxed and focused learning process; (4) Can motivate each other with a group of friends to learn English vocabulary together; and (5) Making students independent and responsible
\end{abstract}

Keywords: cooperative learning, STAD, vocabulary, simple sentences

\section{Introduction}

Language is a very important communication tool in life. We cannot be separated from language in carrying out daily activities because language has a central role in various individual developments, be it intellectual, social, or emotional. Learning languages should not only learn mother tongue, but need to learn foreign languages which will be very useful in life. One of the foreign languages is English. English as a foreign language taught in formal schools, starting from elementary school to tertiary level. Obtaining a second language, especially foreign languages that are obtained in the classroom, of course, more is done with the 
learning system. Learning English starting at the elementary school level gives elementary students the opportunity to learn English.

In mastering language, children are certainly easier to understand and make sentences in their mother tongue compared to mastering a second language (English, for example). The first thing that is mastered by children in language is the component of sound, word order and sentence structure which is the process of language acquisition (Chaer, 2003). In obtaining the child's language not only through natural features, but also determined by cognitive development. Language-based learning activities will fundamentally depend on students' understanding of vocabulary. Students must have access to the meaning of the words used by the teacher and the surrounding environment. The limited understanding of student vocabulary results in impeded achievement of language competence. Referring to the mastery of second language in formal education, namely through education in schools, according to Ellis (in Chaer, 2003: 243), there are two types of language learning, namely the naturalistic type and the formal type in the classroom. The naturalistic type is natural, teacherless and accidental. Learning takes place in family life and community life. The second type is formal in class, but in reality the results are still not satisfactory. The causes are many factors that influence even though there have been various upgrading and training given to educators.

Rivers (in Nunan, 1991: 117) states that vocabulary is important in order to master a second language. Without extensive vocabulary, one cannot use the structure and function of language in communication comprehensively. Obtaining concrete or real vocabulary is easy for students to learn. None of the students had difficulty learning numbers, days, colors, objects and the like. Difficulties arise in the use of words in sentences, verbs, and adjectives. Students tend to forget the inflected forms of nouns, adjectives and verbs, unless they learn gender and plural from the nouns or the correct form of adjectives. They will have difficulty placing nouns or adjectives in sentences unless they know the form of verbs. They cannot use verbs properly in speaking and writing (Tarigan, 1986: 10).

In the process of learning English at SDN 9 Kesiman, educators still apply conventional methods in their teaching practices, such as lecture methods and contextual methods. This method has several weaknesses, such as students whose ability is lacking will always be left behind and students will have difficulty understanding the lessons given. Teaching using STAD (student team achievement division) cooperative methods can make the learning process more productive and make it easier for students to understand the material taught by previous educators. This STAD type of cooperative method gives each student the opportunity to learn independently with their respective groups, so that students with less ability can learn with students who are smarter. This cooperative type method also teaches students can be responsible and have the same success in absorbing material provided by the teacher. The selection of grade 5 students at SDN 9 Kesiman is based on the fact that students have been taught simple sentences in depth. This needs attention because the ability of students in making simple sentences is still lacking, this can be seen when students answer the pretest given by 19 students $(82, .5 \%)$ still do not meet the standard values. This type of STAD cooperative learning method is expected to make it easier for students to master and remember lessons that have been given and can motivate student learning so that learning completeness is in accordance with the curriculum. Thus the teaching and learning process will work well.

\section{Concepts and Theoritical Framework}

\section{A.. Cooperative Learning Type of STAD}


Cooperative learning model is a series of learning activities carried out by students in certain groups to achieve the learning objectives that have been formulated. Abdurahman and Bintoro (2000: 78) say that cooperative learning is learning that consciously and systematically develops positive interactions, caring, and caring for fellow students as an exercise in living in a real society. Slavin greetings Isjoni (2009: 15) cooperative learning is a learning model where students learn and work in small groups collaboratively with 5 members with heterogeneous group structures.

Slavin (2005: 143) states that the STAD (Student Team Achievement Division) cooperative learning model is the simplest learning model and is most appropriate for teachers who are just starting to use approaches with cooperative learning. This learning model aims to motivate students to be able to support each other and help each other so as to increase learning activities, which in the end the learning outcomes will increase. The STAD (Student Team Achievement Division) cooperative type was developed by Robert Slavin et al. At John Hopkin University and is the simplest type of cooperative learning that emphasizes the activities and interactions between students and students to motivate each other and help in understanding a subject matter. According to Dian (2011), "STAD type cooperative learning is one of the models of cooperative learning where students learn with the help of worksheets as a guideline in groups, discussing in order to understand concepts, find the right results". All members are given responsibility, all students are individually given a test that will affect the evaluation of the whole group, which consists of 4-5 people. Each team or group should have heterogeneous members both gender (male and female), race, ethnicity, and various abilities (high, medium, low) Each team member uses academic worksheets (student worksheets) and then helps each other to master teaching materials through question and answer or discussion among fellow team members individually or in teams, every one or two weeks an evaluation is held to find out their mastery of academic material that has been studied. Each student and each team is given a score of authority over teaching material, and individual or team students who achieve high achievements or obtain perfect scores are given awards.

\section{B.Vocabulary and Simple Sentence}

According to Nurgiyantoro (2000: 146), vocabulary is a vocabulary or whatever is owned by a language. According to Kridalaksana (2001: 89) states that vocabulary is wealth owned by a reader or writer of a language. From some of the above meanings, it can be concluded that vocabulary is one component of language, and there is no language without words. The word is a sign or symbols to express ideas or an idea. These words are tools used to exchange ideas. The more words used by a person the more ideas or ideas that he masters, so that he can or is able to communicate his ideas well and effectively. Related to this, vocabulary is the most important element students must have in achieving the four language skills. In relation to the scope of vocabulary, Tarigan (1983: 9) states that basic vocabulary can be chosen as family, part of body, pronoun, numeral, verb, adjective, and universal.

Simple sentences are a series of words that are interconnected in one clause and can stand alone. For example: decorate the cake with strawberries. The boy knew the answer (Droga Louise and Sally Humprey, 2003: 25) The grammar component consists of components which have categories and are interconnected to form a sentence. These components are lexical according to their categories in contextual markers. The markers are syntactic, semantic, and phonological which are indicated as transformations in conveying intentions and thoughts, sentences have a functional relationship consisting of subject, predicate, and object (Menyuk, 1972: 23). Differences in simple sentence forms are generated based on a series of word elements, such as positive sentence form (declarative sentence), negative sentence (negative sentence), Question sentence (introgative sentence). 


\section{The Theory of Language Mistake}

According to Dulay (1982: 139), learning a second language (English) students are not free from mistakes. This theory is used to find out about any mistakes made by students in making simple sentences such as grammatical morphemes, double marking, regulatzing, archiform, alternation form, and misordering.

\section{Method}

This research use an experimental method with one group pretest-posttest design. Sanjaya (2013: 86) states that experimental research methods in education are research methods used to determine the effect of a particular action or treatment that is intentionally carried out on a particular condition. Data collection was carried out by observing, two test sessions namely pretest and posttest, and giving questionnaires. After that the data obtained were analyzed quantitatively and qualitatively.

\section{Result and Discussion}

\section{A. Mastery of Student Vocabulary in Making Simple English Sentences Before Application of STAD}

Pretest is done before applying STAD to extract data or initial description of students' vocabulary mastery in building simple sentences at this time. In addition, STAD can also motivate students to study hard in class. As explained before, the pretest comes in the form of answering objective questions and making simple sentences to find out the extent of mastery of students' vocabulary. The results of the data are analyzed using Dulay's (1982) language error theory where the aspects considered are ommitinggrammatical morphemes, double marking, regulatzing, archiform, alternation form, and misordering. Based on the pretest scores, it is known that the average results of students are 47.5 where the students with the highest scores reach 95 and 20 as the lowest. From this result, 19 students $(62.5 \%)$ had not yet reached the standard completeness score of $\geq 55$ while only 11 students (37.5\%) had reached this minimum standard. The number of students who have not met is far higher than those who fulfill. In other words, it can be interpreted that students' vocabulary mastery in making simple sentences is currently very low and needs to be improved.

\section{B. Mastery of Student Vocabulary in Making Simple English Sentences After Application of STAD}

Pretest is done before applying STAD to extract data or initial description of students' vocabulary mastery in building simple sentences at this time. In addition, STAD can also motivate students to study hard in class. As explained before, the pretest comes in the form of answering objective questions and makes simple sentences to find out the extent of mastery of students' vocabulary. The results of the data are analyzed using Dulay's (1982) language error theory where the aspects are considered to be dramatic mathematical themes, double marking, regulatzing, archiform, alternation form, and misordering. Based on the pretest scores, it is known that the average results of students are 47.5 where the students with the highest scores reach 95 and 20 as the lowest. From this result, 19 students (62.5\%) had not yet reached the standard completeness score of $\geq 55$ while only 11 students $(37.5 \%)$ had reached this minimum standard. The number of students who have not met is far higher than those who fulfill. In other words, it can be interpreted that students' vocabulary mastery in making simple sentences is currently very low and needs to be improved.

\section{The Efectiveness Cooperative Learning Type of STAD to Implementation on Improving Student} Vocabulary Mastery in making simple English sentences 
Observations made are not limited to the learning process in the classroom such as activities to fill in observation forms but also include questionnaire forms. Questionnaires are being carried out after the learning process is completed to collect data related to the effectiveness of the application of the STAD learning model that affects students' mastery of vocabulary building simple sentences in English. Based on the results of the questionnaire, students gave a positive response in the application of STAD vocabulary mastery learning process to build simple English sentences. In the 10-point questionnaire, the majority of students chose 'agree' which reflected their interest in STAD. In addition, their answers in the questionnaire also contribute to the effectiveness of the application of STAD which affects the improvement of students' vocabulary mastery in making simple English sentences at this time, the effect is: (1) a non-boring class atmosphere; (2) Students become confident with their abilities; (3) a much more effective, relaxed and focused learning process; (4) dare to express opinions; and (5) motivating students to always learn independently for groups.

\section{Conclusions}

1) From the results of qualitative analysis, the students' vocabulary mastery ability in making simple sentences today after applying STAD has increased. Qualitative improvement can be seen through the results of observations where students show their interest in learning, participation, and their significant proactivity in attending classes during STAD. In addition to the results of this qualitative analysis, a significant increase was also shown quantitatively based on the results of the posttest analyzed. 27 students or $87.5 \%$ reached the minimum completeness standard of $>60$ while 3 students or $12.5 \%$ had not reached the completeness standard. The grade average grade was 77.8 which was categorized as good. This concludes that STAD has an influence on student learning outcomes.

2) Based on students 'responses from the questionnaire, the effectiveness of the application of STAD that affects the improvement of students' vocabulary mastery in making simple English sentences at this time, the effect is: (1) making the classroom atmosphere not boring; (2) Students become confident with their abilities; (3) a much more effective, relaxed and focused learning process; (4) dare to express opinions; and (5) can motivate students to always learn independently for groups.

\section{Referensi}

Arikunto, Suharsimi. 2016. Dasar-Dasar Evaluasi Pendidikan. Jakarta: PT Bumi Aksara.

Astori, Mohammad.2008. Psikologi Pembelajaran. Bandung: Wacana Primaw

Brown, H Douglas.2000. Principle of Language Learning and Teaching. San Fransisco: Fransisco State

Univesity. Chaer, A. 2003. Psikolinguistik Kajian Teoritik, Jakarta: PT Rineka Cipta.

Chaer,A. 2004. Sosiolinguistik Perkenalan Awal. Jakarta: PT Rineka Cipta.

Dawud. 1997. Pola Asosiasi Kata dalam Pemerolehan Kalimat.

Dardjowidjojo, S. 2003. Psikolinguistik Pengantar Pemahaman Bahasa Manusia. Jakarta: Yayasan Obor Indonesia.

Droga Louise dan Sally Humpryc.2003. Grammar and Meaning: An Introduction for Primary Teachers. Australia. 
Dulay, Heidi. 1982. Langauge Two. New York: Export University Press.

Edward dan Rebecca. 1986. Classroom Techniques: Foreign Languages and English as a Second Language. London Sydney Toronto: Harcourt Brace Jovanovich. 